\title{
STATE OF FORMATION OF COMMUNICATIVE COMPETENCE IN CHILDREN OF SENIOR PRESCHOOL AGE WITH MOTOR ALALIA
}

\section{Baranets}

The article highlights the issues of the current state of development of the communicative-speech activity of older preschool children with speech disorders, the article considers the views on the problem of organizing correctional and developmental work with children with motor alalia. The results of the study of the state of formation of communicative competence in older preschool children with motor alalia and children with normotypic speech development are presented.

The analysis of the results of the study of the state of formation of communicative competence in older preschool children with motor alalia confirmed the relevance of the study.

Criteria with the corresponding indicators of formation of communicative competence of the specified category of children are defined, forms of speech (expressive and impressive) with their nonverbal manifestations in communication and communicative skills in various forms of interactive communication acted as criteria.

The levels of formation of communicative competence are highlighted, in particular: high, sufficient, medium and low.

According to the results of the experiment, it was found, that children with motor alalia have a significantly lower level of formation of communicative competence, in contrast to children with normotypic speech development, which leads to the need to create special psychological and pedagogical conditions for the formation of communicative competence in older preschool children with motor alalia, based on modern complex-integration approach in correctional speech therapy work

Keywords: communicative competence; children with motor alalia; criteria; indicators

Copyright (C) 2020, I. Baranets.

This is an open access article under the CC BY license (http://creativecommons.org/licenses/by/4.0).

\section{Introduction}

The development state of correcting-developing work is characterized by the improvement of the scientific-theoretical and methodical aspect of children's speech examination, development of integrated complex arrangements and methods for creating individual correcting programs, providing child's personal development, including communicative one. That is why at this research stage, it is urgent to determine the communicative competence formation state in children with motor alalia as an obligatory precondition on the way to its effective formation.

\section{Literary review}

Numerous studies of educators and psychologists are devoted to organization peculiarities of the learningupbringing process with children of senior preschool age with speech development disorders $[1,2]$. But integral research methods for the communicative competence in children of senior preschool age with motor alalia that would elucidate all its sides that are verbal and nonverbal communication means, communicative skills in different forms of interactive communication are absent in studies of Ukrainian scientists. Many scientific works of researchers [3-5] elucidate separate sides and list different peculiarities of communicative activity, but the authors are based on the communicative competence understanding as a psychological system, defined by L. Vigotsky - this is an indissoluble integrity of a series of functions or functioning of systems. At that the process of communicative competence formation is considered as a functional system, combining several independent structural units with subordinated mutually conditioned characteristics, formed in certain age periods of child's development.

So, the results of the theoretical analysis of linguodidactic, linguistic literature in logopedic theory and practice on the problem of communicative competence formation in children with motor alalia testify to the absence of integral studies of its formation state.

\section{Research aim and tasks}

The aim of the research is to study the communicative competence formation state in children of senior preschool age with motor alalia as a necessary age psychological achievement of the preschool childhood period, completeness characteristics of tasks and aim of preschool education and program state documents.

The following tasks were outlined for realizing this aim:

- to determine criteria, indicators and levels of communicative competence formation in children of senior preschool age with motor alalia;

- to disclose the communicative competence formation state and peculiarities in children of senior preschool age with motor alalia in pedagogical practice according to the determined criteria and indicators. 


\section{Materials and methods}

The experiment included 126 children: 76 children with motor alalia, 50 children with normotypic speech development.

The diagnostic method of the ascertaining research stage was grounded on traditional methodical principles of complex examination of children with motor alalia in the process of psychological-pedagogical testing, logopedic examination, determination of the development level of communicative-speaking activity components, namely: impressive and expressive speech with their nonverbal manifestations and communicative skills in different forms (dialogue, monologue) of communicative interaction that gives a wider image and idea about the communicative competence formation state and peculiarities of a child of senior preschool age in whole. The method was developed using existing adapted diagnostic methods (T. Vizel [6], N. Pavlova [7], N. Parkhomova [2], T. Pirozhenko [5], E. Sobotovych [8] and other), and corresponding to requirements of educational programs of preschool educational institutions and basic component of preschool education on language and speed development.

The first stage of the ascertaining experiment provided determination of structural components - basic aspects of the communicative components, their criteria and indicators, coordination of actions as parts of the whole, providing communicative-speaking activity, including the competence in communication. Existing methods of logopedic and psychological examination of children with speech disorders, which aspects determine the communicative component $[1,7,8]$, include the complete and expanded research block in speaking and communicative activity, but it is not enough for explaining the communicative competence formation state in children of senior preschool age with motor alalia.

Thus, elaboration of the method for diagnosing the state of communicative-speaking activity components became the first stage in creating the integral system of communicative competence formation in children of senior preschool age with motor alalia.

According to requirements of the system approach, allowing to trace the development of each system component, to explain the dynamics of internal and external connections with other systems, concrete content of each component of communicative-speaking activity as a psychological system, providing practical mastering of verbal and nonverbal communication with the effective use of communicative skills, determining the level of communicative competence formation in a child that is an indicator of cognitive development and precondition of further successful learning at school [9], there are reasons to think that the communicative competence develops as an integral system, including all these components. Taking into account interconnections and mutual determination of system elements, insufficient development of any one of them can decelerate the formation of others. This statement underlines the importance of communication competence diagnostics in children for conducting timely correcting work. The use of conventional methods for diagnosing speaking development of children of senior preschool age usually gives fragmental information about communicative-speaking activity and in fact excludes a possibility to analyze the ratio of obtained data. For overcoming this defect, the system of quality and quantity evaluation of the children's competence and methodical ways for fixing differences of its levels and revelation of individual variations were determined.

So, diagnostication of the communicative competence provided:

- collection and use of a series of methods, allowing to reveal practical abilities and skills, based on direct perception of speech materials and empirical knowledge in the process of task completion;

- collection and use of methods, including tasks, for completing which a child must analyze speech materials from a certain point of view and to manifest own abilities and creativity;

- evaluation of the effectiveness of tasks completion and comparative analysis of obtained data, constructing on their base the integral image of levels of the individual and group communicative competence in children of senior preschool age with motor alalia by the following indicators: a) success of completion of concrete tasks on speech materials; b) character of completion and evenness or unevenness of communicative development components; c) types of mistakes, made by children at completion of tasks.

Communicative competence criteria were speaking forms (impressive and expressive) with their nonverbal manifestations in communication and communicative skills in different forms of interactive communication.

A conventional evaluation standard for the communicative competence formation state in children with motor alalia is the psycholinguistic periodization of speaking development of a child with normotypic ontogenesis (E. Sobotobych) that gives a possibility to determine not only the level of child's speaking development, but to reveal its lag from the age norm [8].

So, in the context of the research the term "criterion" is considered as a measure for evaluating improvements that took place in the development of separate components or childrens' peculiarities in whole as a result of the process of their communicative competence formation. The determined criteria give a possibility to explain formation peculiarities of communicativespeaking activity and its most essential changes, taking place in the process of communicative competence formation at preschool educational institutions, based on comparison with results of children without speaking disorders and also at communicative competence formation as a result of the purposeful correctingdeveloping influence.

Let's characterize indicators by each criterion:

Formation of impressive speech by indicators: volume and quality of the passive vocabulary (understanding and distinguishing of subject names, close by sounding and meaning, understanding and distinguishing of words, close by sounding, understanding and distinguishing of actions, close by meaning); understanding of addressed speech (verbal instructions, requests and orders, words or phrases); speaking attention development, ability to listen attentively to speech, to concentrate attention on speech perception; understanding of words of different grammar categories and complete syntactic 
constructions; formation of processes of probable prognostication at the impressive level, study of the phenomenon of impressive agrammatism.

Formation indicators of nonverbal processes in impressive speech: understanding of an emotional condition of other people; ability to present a motor reaction as a response to a verbal instruction; understanding of an emotional behavior of a collocutor by mimicry and gestures.

Formation indicators of expressive speech, especially: phonetic-phonemic processes: correct sound pronunciation, development of phonemic hearing, formation of phonemic images, ability to phonemic analysis and synthesis, intonation saturation and expression of speech (voice power, speech tempo, intonation), formation of processes of probable prognostication at the expressive level, correct speaking breath; lexical-grammatical aspect of speech: sufficient vocabulary, understanding of semantics of words and their use in the correct semantic meaning, use of words in the correct grammatical form (morphological correctness, mastering of word replacement and word creation), correct grammatical and syntactical language construction, complete sentences in speech; coherent speech with a prosodic decoration: ability to construct a dialogue, ability to retell a text, to compose creative takes, intonation saturation and expressiveness of speech (intonation decoration, logic accents, sounding power, voice modulation, timbre and so on).

Formation indicators of nonverbal processes in expressive speech: motivation to communication, formation of the sensorimotor sphere (general and detailed motility, oral praxis), development of higher psychic functions, formation of processes of interfunctional interaction between cerebral hemispheres.

Formation indicators of communicative skills in different forms (monologue and dialogue) of interactive communication, especially: in monologue speech: ability to express a request, ability to salute, ability to express assent or discord, ability to express own ideas and intentions clearly (free speech), ability to speak about own feelings; in dialogue speech: ability to ask questions politely, ability to understand a situation of communication, intentions and motives of a collocutor, ability to initiate, to support and to finish a conversation, ability to waive, to be honest at communication, ability to assess an emotional behavior of a collocutor by intonation, ability to manifest empathy (to be tactful, to care, to share feelings).

These indicators represent the quantity characteristic of separate components of the communicative competence together with their quality determination of formation levels. Integral indicators of the communicative competence formation state in children of senior preschool age or its separate components must be combined in a certain system, based on which a general idea about quality changes in communicative competence formation and personal child's attitude may be generated. Just formation indicators of impressive and expressive speech with their nonverbal manifestations and ones of communication skills formation in different spheres of interaction (monologue, dialogue) give a possibility to reveal the effectiveness of correctingdeveloping work with senior preschool children with motor alalia, directed on the development of their communicative-speaking activity.

For the convenient deduction of a quantity characteristic of each task completion by a child, the four-point evaluation scale was used. Analyzing psychologicalpedagogical literature on the problem of communicative competence formation, we came to a conclusion that the level of communicative-speaking actions is determined by correctness, distinctness of tasks completion, independence and creativity of each child.

So, depending on completion way and evaluation of tasks by the determined criteria and indicators, the communicative competence formation state in children of senior preschool age was ranged by four levels:

- high level (4 points) - has communication knowledge, abilities and skills, standard for the age group, directed on constructive interaction with adults and coevals, willingly expresses initiative in communication, acts creatively at tasks completion, components of impressive and expressive speech with their non-verbal components are formed (understands an emotional behavior of a collocutor by mimicry and gestures, is able to express a request, assent or discord and so on);

- sufficient level (from 3 to 4 points) - has communication knowledge, abilities and skills, experience, used independently, expresses initiative in communication, manifests assuredness, ability to accept help from adults in actions, completes all or most tasks, can distinguish emotional conditions of a collocutor, starts a dialogue, actively maintains a conversation;

- middle level (from 2 to 3 points) - has communication knowledge, abilities and skills, experience, but not always uses them in communicative activity and new situation, communication with adults dominates, feeling of diffidence in relations with coevals, absence of initiative in common activity, sometimes refuses of tasks completion, not always accepts and uses help, most often completes tasks by the concrete instruction and help;

- low level (from 0-2 points) - has no communication knowledge, abilities and skills, practical activity experience, sometimes refuses of tasks completion, doesn't accept and doesn't use help, most often cannot complete a task by the concrete instruction and help, demonstrates unwillingness to establish a constructive interaction at all.

Thus, the communicative competence of a preschool child is understood by us as formation and certain development level of impressive and expressive speech with their nonverbal manifestations in different forms of interaction (monologue, dialogue).

\section{Research results and their discussion}

The experimental diagnostic method, as opposite to existing ones, contains concrete tasks for determining the formation level of verbal and nonverbal manifestations of impressive and expressive speech, because according to O. Luriya, "it is quite clear, that extra-speech components: mimicry, gestures also participate in the process of formation and decoding together with the system of linguistic units" [10]. They form "a functionally independent semiotic system", which helps to transmit also some forms of nonverbal behavior, characterizing a condition of the motivation-emotional sphere and inte- 
gral behavioral structures and programs. These components illustrate not only emotional reflections of a person, but create a general image of its mental orientation, connected with an effect of the total conglomerate of factors, forming the uniqueness of each individual manifestation that in whole gives an idea of communicative competence formation state in children of senior preschool age.

One more peculiarity of the experimental method is the interdisciplinary approach to differential diagnostics of motor alalia in children. Just the involvement of specialists of the medical field favored the objective differential diagnostics in children with hard speaking disorders. Because just integration of the medical component into the correcting work of a speech therapist allows to separate a speech disorder at the initial stage by a certain nosological category and, undoubtedly, doesn't diminish the importance of the psychological-pedagogical aspect comparing with the medical one. We completely agree with the statement by O. Luriya [10], who wrote: "creation of the scientifically substantiated doctrine about the development of an abnormal child, correct revelation, evaluation of his/her defects, finding of rational ways of his/her education - all that is impossible without using the integral system of clinical, experimentalpsychological and pathophysiological studies".

So, the comparative result data of the experimental diagnostic method testify to essential differences between tasks completion in levels of impressive and expressive speech with their non-verbal manifestations and communicative skills in different forms of interaction (monologue, dialogue). So, the results of the conducted study allowed to establish, that children with the high and sufficient level of communicative competence formation were not revealed among ones with motor alalia, only $25 \%$ of children with motor alalia have the middle level of communicative competence formation. The low level was demonstrated by $75 \%$ of children.

Children with the normotypic speech development demonstrated rather high indices of communicative competence formation, the high level in $8.3 \%$ of children, sufficient level - in $83.4 \%$, and middle level $-8.3 \%$. The low level of communicative competence formation was not revealed among them.

Thus, a child with motor alalia cannot reach the high and sufficient levels of communicative competence formation as a result of non-formation of structural components of speaking activity that is most brightly expressed in the process of communicative interaction, without the specially organized system of correctingpedagogical work that undoubtedly takes into account the whole originality of the process of speech formation of such children.

The revealed peculiarities reflect the specificity of speech development disorders of this category of children and must be taken into account at elaborating correspondent content lines of the correcting-developing process of communicative competence formation in senior preschool children with motor alalia.

The levels of communicative competence formation in senior preschool children with motor alalia and ones without speaking disorders have been determined by the formation indicators of the communicativespeaking system components, the results are presented on Fig. 1.

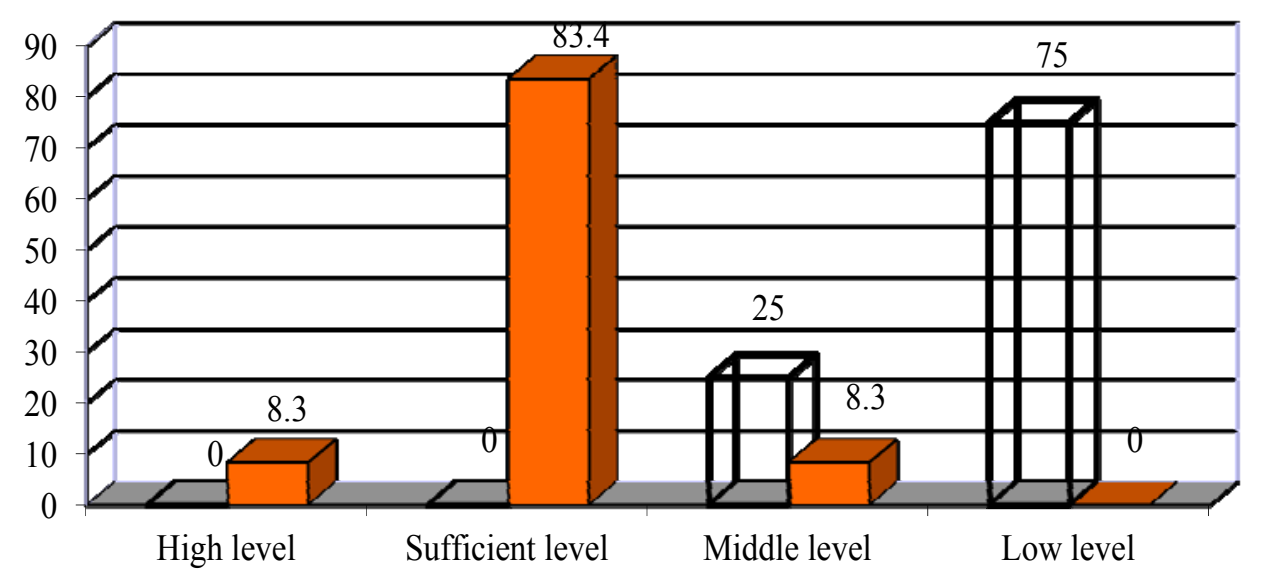

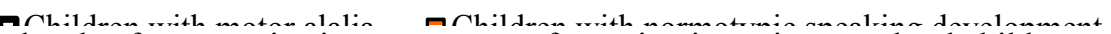

Fig. 1. Comparison of the levels of communicative competence formation in senior preschool children with motor alalia and ones with normotypic speaking development

\section{Conclusions}

The criteria, indicators and levels of communicative competence formation in senior preschool children with motor alalia have been determined. The criteria were the speaking forms (impressive and expressive) with their nonverbal manifestations and communicative skills in different forms of interactive communication. The determined criteria gave a possibility to explain peculiarities of communicative-speaking activity formation and its most essential changes, taking place in the process of communicative competence formation. Depending on ways of tasks completion and evaluation by the determined criteria, the state of communicative competence formation in senior preschool children was divided in four levels: high, sufficient, middle, low.

The research has elucidated the formation state and peculiarities of communicative competence in senior preschool children. The revealed peculiarities reflect the 
specificity of speech development disorders of this category of children and must be taken into account at elaborating correspondent content lines of the correctingdeveloping process of communicative competence formation in senior preschool children with motor alalia. Based on the analysis of the obtained research results, it has been established, that children with motor alalia have the essentially lower level of communicative competence formation (middle level - $25 \%$ of children, low level $75 \%$ of children) as opposite to ones with the normotypic development type (high level $-8.3 \%$ of children, suf- ficient level - $83.4 \%$, middle level $-8.3 \%$.), that conditions the necessity to create the system of psychologicalpedagogical conditions for communicative competence formation in children with motor alalia, based on modern complex-integrated approaches to the process of correcting-logopedic work.

Prospects of further studies are in elaboration of the method for communicative competence formation in senior preschool children with motor alalia, taking into account the obtained results of the ascertaining stage of the experiment.

\section{References}

1. Bohush, A. M., Havrysh, N. V. (2015). Doshkilna linhvodydaktyka : teoriia i metodyka navchannia ditei ridnoi movy v doshkilnykh navchalnykh zakladakh. Kyiv: Vydavnychyi Dim «Slovo», 704.

2. Sheremet, M. K., Pakhomova, N. H. (2009). Formuvannia movlennievoi hotovnosti ditei starshoho doshkilnoho viku z porushenniamy movlennia do navchannia v shkoli. Kyiv: Nats. ped. un-t im. M. P. Drahomanova, 137.

3. Bohush, A. M. (2004). Movlennievyi komponent doshkilnoi osvity. Odesa: Yaroslav, 176.

4. Kalmykova, L. (2015). Movlennieva diialnist yak skladova chastyna predmeta psykholinhvistyky. East European Journal of Psycholinguistics, 2 (1), 59-67.

5. Pirozhenko, T. O. (2013). Komunikatyvno-movlennievyi rozvytok doshkilnyka. Ternopil: Mandrivets, 152.

6. Vizel, T. G. (2018). Artikuliatsiia i ee narusheniia: (teoreticheskii aspekt s pozitsii neiropsikhologii). Spetsialnoe obrazovanie, 3 (51), 123-135.

7. Pavlova, N. V. (2017). Formuvannia komunikatyvnoi aktyvnosti u nemovlennievykh ditei molodshoho doshkilnoho viku zasobamy innovatsiinykh tekhnolohii. Odesa: DZ «Pivdennoukr. nats. ped.un-t im. K.D. Ushynskoho», 210.

8. Sobotovych, Ye. F. (2003). Kryterii otsiniuvannia movlennievoho rozvytku dytyny (u yoho leksychnii lantsi) na riznykh vikovykh etapakh. Defektolohiia, 2, 2-7.

9. Zhukovskyy, V. (2017). The role of the teacher in the process of forming the communicative competence of the junior pupils based on the structural approach to personality. ScienceRise: Pedagogical Education, 12 (20), 48-54. doi: http://doi.org/10.15587/2519-4984.2017.120051

10. Luriia, A. R. (2000). Vysshie korkovye funktsii cheloveka i ikh narusheniia pri lokalnykh porazheniiakh mozga. Moscow: Izd-vo Akadem. Proekt, 282.

Received date 18.10.2020

Accepted date 16.11.2020

Published date 25.12.2020

Inna Baranets, Postgraduate Student, Mykola Yarmachenko Institute of Special Pedagogy and Psychology of the National Academy of Pedagogical Sciences of Ukraine, M. Berlynskoho str., 9, Kyiv, Ukraine, 04060, Assistant, Department of Special Education and Social Work, Poltava V. G. Korolenko National Pedagogical University, Ostrohradskoho str., 2, Poltava, Ukraine, 36000

Email: inessaibk@gmail.com 